\title{
A Review of the Methods Used by the U.S. Environmental Protection Agency to Assess the Financial Impacts of the Repository Regulations
}

\section{Prepared for the U.S Department of Energy}

by

Chris G. Pflum

Steven R. Mattson*

August C. Matthusen*
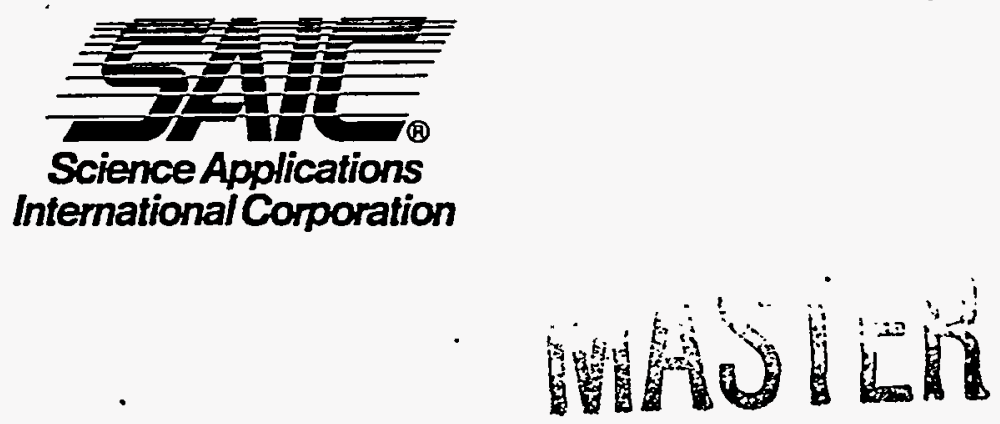

February 16, 1994

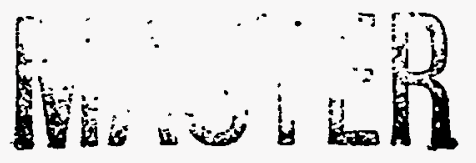

* Presently at Woodward-Clyde, Federal Services 


\section{Contents}

Executive Summary $\ldots \ldots \ldots \ldots \ldots \ldots \ldots \ldots \ldots \ldots \ldots \ldots \ldots$ iii

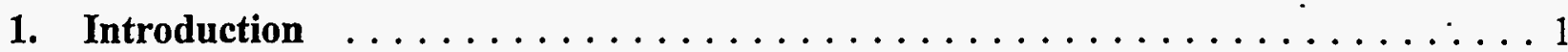

2. Summary of the Regulatory Impact Analysis Prepared by the U.S. Environmental Protection Agency $\ldots \ldots \ldots \ldots \ldots \ldots \ldots \ldots \ldots \ldots$

3. A Review of the Regulatory Impact Analysis (RIA ) Prepared by the U.S. Environmental Protection Agency ...............6 6

3.1 Overview of the RIA and Manipulation of Policy Variables $\ldots \ldots \ldots \ldots 6$

3.2 Health Effect Analysis Within the RIA .................. 7

3.3 Regulatory Costs Presented in RIA .................. 11

Appendix A: Selected Regulatory Activities and Products $\ldots \ldots \ldots \ldots \ldots \ldots 14$

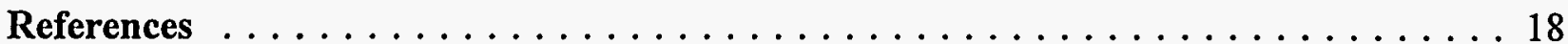

\section{DISCLAIMER}

This report was prepared as an account of work sponsored by an agency of the United States Government. Neither the United States Government nor any agency thereof, nor any of their employees, makes any warranty, express or implied, or assumes any legal liability or responsibility for the accuracy, completeness, or usefulness of any information, apparatus, product, or process disclosed, or represents that its use would not infringe privately owned rights. Reference herein to any specific commercial product; process, or service by trade name, trademark, manufacturer, or otherwise does not necessarily constitute or imply its endorsement, recommendation, or favoring by the United States Government or any agency thereof. The views and opinions of authors expressed herein do not necessarily state or reflect those of the United States Government or any agency thereof. 


\section{DISCLAIMER}

Portions of this document may be illegible in electronic image products. Images are produced from the best available original document. 


\section{Tables}

2-1 Options for a Tuff Repository $\ldots \ldots \ldots \ldots \ldots \ldots \ldots \ldots \ldots$

3-1 EPA Assessment of the Standards' Achievability vs.

DOE Assessment of Compliance with the Standards $\ldots \ldots \ldots \ldots \ldots$

A-1 Cost of Meetings Between the NRC and DOE $\ldots \ldots \ldots \ldots \ldots \ldots$ 


\section{Executive Summary}

In August, 1992, the U.S. Environmental Protection Agency (EPA) issued a draft "Regulatory Impact Analysis for EPA's High-Level Waste Standards (40 CFR Part 191)" (EPA, 1992). The Regulatory Impact Analysis (RIA) concludes that compliance with the EPA standards does not increase costs above what the U.S. Department of Energy (DOE) would have spent anyway, or at most, what the DOE would spend to comply with the regulation promulgated by the Nuclear Regulatory Commission (NRC), 10 CFR Part 60. This analysis strongly disagrees with the EPA cost estimates and disagrees with the way in which the RIA was performed.

The EPA introduced the notion that a repository can be proven safe for 10,000 years, but the RIA does not assess in an equitable or accurate manner the cost of developing this proof. The EPA disregards uncertainties and would have us believe that over a period of 10,000 years, the repository regulations would avert precisely thirty five (35) health effects. The EPA attaches a discounted cost to each (undiscounted) health effect or "benefit" and concludes that its regulations do not increase costs beyond what the DOE would spend anyway. Accordingly, the EPA estimates the total costs (1988 dollars) to characterize Yucca Mountain and build a repository at $\$ 4.653$ billion which includes regulatory costs of $\$ 0.601$ billion.

We recommend that in future regulatory impact analyses the EPA should not compare discounted costs to benefits that are not discounted. Any comparison of discounted costs to undiscounted benefits would excuse the most exorbitant expenditures particularly when costs are discounted over decades, but benefits that accrue over millennia are not discounted. Even if EPA could find an equitable way to compare short-term costs to the number of long-term health effects that the regulations would avert (i.e., benefits), we doubt that the comparison would be meaningful. While costs can be predicted fairly accurately, benefits cannot. The EPA found that current regulations allow only three (3) more health effects than more stringent regulations. Had EPA considered the uncertainties in these projected health effects, there would be no difference between the regulations.

The EPA should abandon its current method for assessing the costs associated with the repository regulations. Rather than deriving costs from constructs that are no longer viable, such as different geologic media and waste forms, the EPA should concentrate on the cost 
savings which might accrue from. fundamentally different approaches to establishing the standards. For example, the EPA should consider:

- standards that protect individuals or local populations rather than the entire world;

- standards that protect for perhaps 1,000 years rather than 10,000 years;

- standards that require perhaps $50 \%$ confidence for 10,000 years rather than $90 \%$ and $99.9 \%$ (see $\mathrm{SAB}, 1984$ );

- standards that impose more equitable limits on releases of gaseous carbon-14; and

- standards that address human intrusion more qualitatively than quantitatively. 


\section{Introduction}

All Federal agencies must consider the financial impacts of their regulations. When costs significantly outweigh benefits, the Office of Management and Budget can recommend that Congress not provide the funds needed to implement the regulation. Without funds, the agency is forced to either revise or retract the regulation. This has happened previously with a regulation on uranium mill tailings proposed by the U.S. Nuclear Regulatory Commission (NRC) and it could happen again with the U.S. Environmental Protection Agency (EPA) regulations that govern the disposal of high-level radioactive waste (HLW).

The EPA $(1985,1992)$ claims that its regulation: "Environmental Standards for the Management and Disposal of Spent Nuclear Fuel, High-Level and Transuranic Radioactive Waste" (40 CFR Part 191 or standards) does not increase costs above what the U.S.

Department of Energy (DOE) would spend anyway or, at most, what the DOE would spend to comply with 10 CFR Part 60: a regulation promulgated by the NRC. This report reviews and disputes the EPA claim. In Chapter 2 a summary of the basis for the EPA claim is presented and in Chapter 3 a critique of the basis of the claim is presented. This critique finds the EPA basis unrealistic, incomplete, and misleading.

According to the EPA, a repository at Yucca Mountain would easily meet 40 CFR Part 191 even without the use of special engineered barriers. Because the NRC regulation (10 CFR Part 60) requires engineered barriers, the EPA places the onus for regulatory costs on the NRC. We disagree; the EPA standards drive regulatory costs as much as NRC regulations. The EPA has the higher responsibility for setting the overall standard for safety while the NRC can only implement this standard. 


\section{Summary of the Regulatory Impact Analysis Prepared by the U.S. Environmental Protection Agency}

In August, 1992, the U.S. Environmental Protection Agency (EPA) issued a draft "Regulatory Impact Analysis For EPA's High-Level Waste Standard (40 CFR Part 191)" (EPA, 1992). The Regulatory Impact Analysis (RIA) concludes that compliance with the EPA standards does not increase costs above what the U.S. Department of Energy (DOE) would spend anyway, or at most, what the DOE would spend to comply with 10 CFR Part 60: a regulation promulgated by the U.S. Nuclear Regulatory Commission (NRC). This chapter summarizes the assumptions and cost estimates that led the EPA to the above conclusion. Portions of the RIA that discuss other geologic media (basalt and salt) and the Waste Isolation Pilot Plant will not be summarized or reviewed in this report.

On July 17, 1987, the U.S. Court of Appeals invalidated Subpart B--the disposal requirements--of 40 CFR Part 191. Since then, the EPA has been in the process of revising its standards. The disposal requirements limit the cumulative number of curies that a repository may release in 10,000 years taking into account "all possible events" that could disturb the repository during that time. A repository that meets these requirements would cause no more than 1,000 health effects per 100,000 metric tons of heavy metal (MTHM) or 700 health effects per 70,000 MTHM (prior to a second repository, the repository's legal capacity). The disposal requirements also include assurance requirements and requirements that protect individuals and ground water for 1,000 years. The assurance requirements "seek to reduce the likelihood of [human] intrusion" (RIA, page 10). The protection requirements ignore low probability events, and according to the RIA, the requirements "call for a 100 percent chance that the limit will not be exceeded in their [low probability events] absence for either 1,000 years or 10,000 years" (page 10) ${ }^{1}$. The RIA examines the costs of complying with the curie limits but not the assurance and protection requirements.

\footnotetext{
${ }^{1}$ The requirements actually call for a "reasonable expectation" that the limits will not be exceeded.
} 
Using different combinations of "policy variables" the EPA developed twelve options ${ }^{2}$, including a reference case, for an unsaturated repository excavated in tuff. These variables, which according to the EPA, "can be manipulated by the EPA or program managers" (RIA, page viii), are: the geologic media in which the repository would be located; the leach rate associated with the waste form; and the life of the canister containing the waste form. The reference case assumed that "processed" waste would leach at a rate of $10^{-5}$ parts per year and that the waste canister would last 300 years. These particular assumptions are consistent with requirements in $10 \mathrm{CFR}$ Part 60 . The options assumed leach rates of $10^{-3}$ to $10^{-6}$ per year and canister lives of 0 and 1,000 years. Leach rates from "unprocessed" waste (i.e., spent fuel) were not known (RIA, page 84) and canisters lasting more than 1,000 years were not considered.

The costs of the options were estimated and then discounted at $2 \%$ over the life cycle of the repository. (Costs were discounted only over the period of construction, operation, decommissioning, and closure; not the full 10,000 year life of the repository.) Generally costs increase as leach rates decrease and as canister longevity increases. The reference case was estimated at $\$ 4.653$ billion (1988 dollars) and the options varied from $\$ 4.052$ billion to $\$ 5.120$ billion (RIA, page 82). Benefits, or health effects that would be averted in 10,000 years, were not discounted. The EPA stated that because the health effects would occur far into the future, any discount rate would reduce them to zero. Taking "all possible events" (RIA, page viii) into account, the reference case was estimated to cause four health effects in 10,000 years and the options varied from 1 to 39 health effects. Table 2-1 presents the policy variables that comprise the reference case and the two most extreme options evaluated for a tuff repository.

In all options, the EPA claims that a tuff repository would easily meet 40 CFR Part 191 even with "no special engineering barriers in place" (RIA, page xi), but 10 CFR Part 60 requires engineered barriers even if they are not otherwise needed. According to the EPA,

\footnotetext{
${ }^{2}$ Twelve options were developed for a tuff repository, twelve for a salt repository and twelve for a basalt repository. As stated earlier, this report will not review the EPA analysis of salt and basalt repositories.
} 


\title{
OPTIONS FOR A TUFF REPOSITORY
}

Option

\author{
Leach Rate
}

(parts/year)
Canister Life
(years)

Health Effects

$(10,000$ years)

Total Cost

(\$billions)

1. Meets EPA

$10^{-3}$

0

39

4.052

2. Meets EPA \& NRC $10^{-5}$

300

4

4.653

3. Exceeds EPA \& NRC 10-6

1,000

1

5.120

Regulatory costs = Option 2 - Option $1=\$ 601$ million Regulatory benefits = Option 2 - Option 1 = 35 health effects averted 
"[The] NRC rule, 10 CFR Part 60, requires that minimum canister life be somewhere between 300 and 1,000 years and waste form leach rates be less than $10^{-5 n}$ (RIA, page xi). These barriers increase costs by "\$28 million per health effect, at most" (page 84 ). Thus the EPA places responsibility on the NRC for regulatory costs and concludes, "If the NRC requirements are met, repositories in all three media studied comply with 40 CFR Part 191" (RIA, page xi).

The EPA disposal requirements also protect ground water and individuals, but the EPA did not assess the costs of this protection. Likewise, the EPA briefly assesses, but does not fully consider, the cost and benefits of possible carbon-14 mitigation.

The EPA assessed that an unsaturated repository may release more gaseous carbon-14 than the standards allow and, at worst, cause 3,000 health effects. The mitigation costs, discounted at $2 \%$ over 50 years, were estimated to range from $\$ 1.4$ billion to $\$ 2.1$ billion. The EPA notes that compliance with 10 CFR Part 60 would prohibit gaseous releases, and only a violation of 10 CFR Part 60 would create a violation of 40 CFR Part 191 (RIA, page 90). This statement strongly implies that the cost of possible gaseous carbon-14 mitigation should be borne by the NRC regulation and not the EPA regulation. 


\section{A Review of the Regulatory Impact Analysis (RIA) Prepared by the U.S. Environmental Prôtection Agency}

\subsection{OVERVIEW OF RIA AND MANIPULATION OF POLICY VARIABLES}

This chapter reviews three major areas presented in the Draft Regulatory Impact Analysis (RIA) (EPA, 1992): 1) manipulation of three policy variables, 2) health effect analysis, and 3) regulatory costs.

The EPA constructed different disposal options by manipulating "policy variables." However, two of these so-called "variables" cannot be manipulated, the third was not fully evaluated, and variables that could affect many of the costs or benefits were not considered.

The Congress, not the EPA, has controlled the first variable: -the geologic media. The RIA evaluated costs for a repository located in the geologic media of salt, basalt, and tuff. When Congress limited studies to Yucca Mountain (NWPAA, 1987) it also mandated volcanic tuff in the unsaturated zone as the only geologic medium. It is doubtful that the EPA policy could over-ride Congress and force the DOE to study different sites and geologic media.

National policy, not the EPA, controls the second variable: the leach rate associated with the waste form. National policy currently advocates the underground disposal of spent nuclear fuel rather than the reprocessing of spent nuclear fuel. The leach rate from spent fuel cannot be significantly controlled or manipulated unless the spent fuel is reprocessed. Although the EPA assumes that all repository wastes would be reprocessed, only the defense waste (about $10 \%$ of the total inventory) would be reprocessed.

The third variable: the life-span of the HLW containers was evaluated using only the values of 0,300 , and 1,000 years for the container life-spans. Other container life-spans could have been evaluated (e.g., 100 or 10,000 years). Long-lived containers may be needed to keep releases of gaseous carbon-14 to within the standards' limit, yet carbon-14 poses little health risk to individuals. 
The EPA overlooked the most important variable: different standards. The EPA could have assessed the cost of complying with less stringent standards or standards that are more qualitative than quantitative. For example, the period of isolation or the level of needed confidence in predictions could have been varied. The present period of isolation is 10,000 years and the levels of confidence have been placed at $90 \%$ and $99.9 \%$. Shorter periods of isolation and/or lower levels of confidence would probably reduce regulatory costs without appreciably changing benefits.

Because the first two variables can not vary, the third was not fully evaluated, and many important variables were not considered at all; the costs and benefits derived from the analysis are unrealistic. Even if the variables and costs were more realistic, the lack of sensitivity analyses and the absence of an evaluation of the accuracy and precision of calculations of the hypothetical health effects undermine the entire analysis.

\subsection{HEALTH EFFECT ANALYSIS WITHIN THE RIA}

The premise that any precaution taken today could avert a precise number of "health effects" ${ }^{13}$ thousands of years from now and that any calculation could accurately predict these health effects is difficult to accept. During the course of 10,000 years between 500 billion $\left(5 \times 10^{11}\right)$ to one trillion $\left(1 \times 10^{12}\right)$ people will die $e^{4}$. The RIA, however, indicates that if the waste form were ten times less soluble, precisely 21 people would live longer than they otherwise would. These 21 people comprise between $4 \times 10^{-9}$ to $2 \times 10^{-9}$ percent of the estimated population that will have lived and died during 10,000 years (21 people out of 500 billion to 1 trillion). Although these 21 health effects are totally hypothetical (even to the degree that some prominent scientists dispute the "health effects" of low levels of radiation; see, for example: Yalow, 1991), the RIA presents them in such

\footnotetext{
${ }^{3}$ The EPA uses the term "Health Effect" to indicate a premature death. However, neither the degree of prematurity nor the rationale for the number of health effects predicted are quantified in the RIA. Does a health effect equate to life shortened by a day, a month, or a year? Additionally, neither the benefits of lives extended by the use of electricity generated from nuclear fuel nor the total number of health effects that would occur from not disposing of the spent fuel are considered.

${ }^{4}$ For illustrative purposes, we assume a constant world population at five billion (current) and ten billion (EPA's assumption) and that each person lives for seventy years.
} 
an absolute manner that they appear as precise predictions, which they are not, and thus are used incorrectly to discriminate one option from another.

The EPA must account for the huge uncertainties surrounding long-term predictions. Model uncertainty alone can cause the number of health effects to vary by a factor of 10 or more $^{5}$, and total uncertainty grows so large at 10,000 years "that demonstrating compliance with the standards is meaningless" (DOE, 1992a). In either case, the uncertainty is large enough to obscure the differences in health effects among all 12 options the EPA considered for a tuff repository. Table 4-3 of the RIA shows that the calculated health effects for different types of tuff repositories vary from 1 to 39 . Just a factor of 10 variation in each extreme gives a low range of 0.1 to 10 and a high range of 3.9 to 390 . Since model uncertainty alone causes the high and low values of the calculated range of values to overlap, the accuracy and precision of EPA calculations are not sufficient to discriminate options for the tuff repository.

The EPA Background Information Document (BID) (Little, 1990) supposedly demonstrates that all options for the tuff repository could easily comply with the present or more stringent standards. For example, the standards for individual protection require that individual exposures through all pathways not exceed 25 millirems. The EPA models of ground-water flow through a tuff repository show no discharge in 10,000 years. As a result of these findings, the EPA concluded that "there is, therefore, no [financial] impact of moving the [exposure] limit down to zero" (EPA, 1992).

The completeness of the conceptual model, level of conservatism, and defensibility of the assumptions in the BID or the RIA does not match the rigor with which DOE must demonstrate compliance with standards. Table 3-1 illustrates some of the differences between the manner in which the EPA demonstrates that the standards can be achieved versus the manner in which the DOE will demonstrate that the standards will be met. While we do not expect EPA to assess a repository's performance as rigorously as the

\footnotetext{
${ }^{5}$ Complementary cumulative distribution functions plotted by Barnard et al. (1991) show that cumulative releases for 10,000 years can vary by a factor of at least 10 depending upon whether fracture or matrix flow is modeled.
} 
DOE, the huge discrepancy between the two assessments indicates that either the EPA has not substantiated its regulations, or the DOE is over-reacting to them.

The EPA estimates that canisters and waste forms needed to satisfy NRC regulations would increase costs by $\$ 28$ million for each health effect that they would avert in 10,000 years. The costs of these engineered barriers are discounted but the benefits (i.e., the number of averted health effects) are not. Clearly, it is not cost-effective to spend millions of contemporary dollars to avert hypothetical deaths thousands of years from now. Indeed, the Fifth Circuit Court ruled, "Because the EPA must discount costs to perform its evaluations properly, the EPA should also discount benefits to preserve an apples-to-apples comparison, even if this entails discounting benefits of a non-monetary nature" (Fifth Cir., 1991). Since any type of benefit discounted over thousands of years would essentially be zero, the EPA should abandon this type of analysis.

Statistics are also misused in conjunction with valuation of costs and benefits to reduce or mitigate release of gaseous carbon-14. On page 91 of the RIA, the text states: "Following on this, a best case assumption can be made that zero health effects would occur from gaseous releases as a result of the [failed] canisters. As a worst case the assumption is approximately 3,000 health effects resulting from a total failure of the canisters to contain the gaseous releases (SCA92) [Sanford Cohen and Associates, 1992]."

The text continues: "These estimates suggest a range for the cost-benefit ratio of C-14 reduction. Combining high cost assumptions ( $\$ 2.1$ billion) with poorest performance of the barrier (reduction of 1 health effect) leader (sic) to a cost-benefit ratio of 2.1 billion per statistical health effect averted. Combining low cost assumptions ( $\$ 1.4$ billion) with best performance (3,000 statistical health effects averted) for the other end of the range gives a bound of $\$ 473,000$ per statistical health effect averted. A midpoint between the two estimates gives a value of $\$ 1.2$ million per health effect averted."

Although the calculations attempt to address the uncertainty by using a range of values, the values used appear to be chosen arbitrarily as no justification is provided for the use of one health effect averted for the poorest performance of the barrier. The first quotation indicates that zero health effects are feasible; therefore, it may be that the health effect reduction may also be zero. Then the high cost assumption would be equal to infinity 


\section{Table 3-1}

\section{EPA ASSESSMENT OF THE STANDARDS' ACHIEVABILITY \\ VS. \\ DOE ASSESSMENT OF COMPLIANCE WITH THE STANDARDS}

\begin{tabular}{|l|l||}
\hline $\begin{array}{l}\text { No consideration of likely natural } \\
\text { disruptive events }\end{array}$ & $\begin{array}{l}\text { Complex analysis of scenarios, } \\
\text { probabilities, consequences of all likely } \\
\text { natural events }\end{array}$ \\
\hline $\begin{array}{l}\text { No alteration to current ground-water flow } \\
\text { regime }\end{array}$ & $\begin{array}{l}\text { Considers natural (climate change, etc.) } \\
\text { effects on ground-water regime }\end{array}$ \\
\hline $\begin{array}{l}\text { Ignores fluid density effects due to } \\
\text { salinity, temperature }\end{array}$ & Considers these effects \\
\hline $\begin{array}{l}\text { Ignores spatial variability in aquifers, } \\
\text { dispersion }\end{array}$ & $\begin{array}{l}\text { Uses sophisticated geostatistical analysis, } \\
\text { dispersion }\end{array}$ \\
\hline $\begin{array}{l}\text { Ignores processes of container and waste } \\
\text { form degradation, and waste/ground water/ } \\
\text { rock/gas interactions }\end{array}$ & Considers these processes \\
\hline Assumes seals work perfectly & Evaluates seals performance in detail \\
\hline $\begin{array}{l}\text { Ignores transport of radionuclides sorbed } \\
\text { onto colloidal particles }\end{array}$ & Evaluates colloidal transport \\
\hline $\begin{array}{l}\text { Simplistic sensitivity analysis for a few } \\
\text { parameters }\end{array}$ & $\begin{array}{l}\text { Full uncertainty and sensitivity analyses } \\
\text { for hundreds of parameters; alternative } \\
\text { conceptual models }\end{array}$ \\
\hline $\begin{array}{l}\text { Does not consider releases of gaseous } \\
\text { carbon-14 }\end{array}$ & Considers releases of gaseous carbon-14 \\
\hline $\begin{array}{l}\text { Assumes pressure-equilibrium between } \\
\text { fractures and rock matrix }\end{array}$ & $\begin{array}{l}\text { Considers details of spatial and temporal } \\
\text { disequilibrium }\end{array}$ \\
\hline $\begin{array}{l}\text { gnores effect of fault zones in both } \\
\text { unsaturated and saturated regions }\end{array}$ & Considers effect of fault zones \\
\hline $\begin{array}{l}\text { Assumes very thick mixing zone in } \\
\text { saturated aquifer (1 km thick) }\end{array}$ & $\begin{array}{l}\text { Considers actual extent of contaminated } \\
\text { zone at water table }\end{array}$ \\
\hline
\end{tabular}

${ }^{6}$ The scope of the DOE compliance assessment may change when EPA issues new standards for Yucca Mountain. 
(i.e., the cost divided by zero), the low cost assumption could be bounded by $\$ 473,000$, and the midpoint between the two could also be equal to infinity ${ }^{7}$. That infinity is the correct value can also be seen by the following quotation from the RIA: "This analysis is based on discounting of the costs and not the health effects that are prevented due to these expenditures. It should be noted that given the time frame over which the health effect would occur (10,000 years) if any positive discount rate were to be applied they would become insignificant."

\subsection{REGULATORY COSTS PRESENTED IN RIA}

The EPA estimated that the least expensive option ${ }^{8}$ for a tuff repository would cost $\$ 4.052$ billion (1988 dollars). The EPA claims that its regulations would not increase these costs but that NRC regulations increase costs by $\$ .601$ billion. The EPA (1992), however, misreads NRC regulations. The EPA thinks that the NRC imposes a leach rate on the waste form (page 71) when, in fact, the NRC specifies a release rate from the engineered barrier system (EBS). A leach rate from a waste form would be more expensive to control than a release rate from the EBS. Leach rate is a function of only one engineered barrier, the waste form (i.e., spent fuel), while release rate is a function of many engineered barriers, such as containers, shielding, packing, absorbent materials, and backfill materials as well as the waste form.

The RIA also states, "If the NRC requirements are met, repositories in all three media studied comply with 40 CFR 191." However, the NRC requirements at 10 CFR 60.113 tolerate higher releases of plutonium and americium (NRC, 1983) than the limits specified in 40 CFR Part 191. Also, these NRC requirements, unlike 40 CFR Part 191, do not seek confidence levels or solicit assessments of human intrusion and extremely rare events. In

\footnotetext{
${ }^{7}$ Indeed, in view of the statistics, if one ran two "experiments" one might find 39 health effects with no barriers and 390 with barriers present, which would result in a negative benefit of -351 !

${ }^{8}$ This option would comply with 40 CFR Part 191 but not the NRC regulation, 10 CFR Part 60 . The EPA claims that 10 CFR Part 60 increases costs by about $\$ 28$ million for each calculated health effect that the regulation averts.
} 
other words, compliance with 10 CFR 60 does not guarantee compliance with 40 CFR 191 and vice versa.

The EPA dismisses any costs associated with its assurance, individual, and ground-water requirements and does not consider the cost of controlling the release of radioactive gases. The assurance requirements ${ }^{9}$ forbid reliance on institutional and physical mechanisms that would discourage human intrusion. Consequently the DOE must assume that humans will inadvertently intrude the repository. The DOE, however, opposes assessing the probability and consequences of human intrusion:

\begin{abstract}
"Releases resulting from human intrusion dominate compliance analyses and may make it impossible to proceed with any deep geologic disposal site because of the difficulties of assigning and justifying probabilities and consequences of occurrences" (DOE, 1991).
\end{abstract}

These assessments of human intrusion, including some test phase work, have cost the Waste Isolation Pilot Plant roughly $\$ 300$ million (Pflum et al., 1993). This expenditure has not improved safety or made the WIPP facility any less susceptible to human intrusion. Were it not for the assurance requirements in 40 CFR Part 191, the authors believe that the $\$ 300$ million could have been saved or spent more productively.

Besides the assurance requirements, requirements that protect individuals and groundwater . are bound to incur costs if the EPA extends this protection to 100,000 years as the RIA and past drafts of 40 CFR Part 191 suggest. The RIA (page 90), however, states:

"For a tuff repository with characteristics similar to the Yucca Mountain site, the individual and ground-water requirements provide an extra protection to populations living near the repositories, but they do not add to the cost of compliance."

\footnotetext{
${ }^{9}$ Although the assurance requirements do not formally apply to Yucca Mountain, the NRC has promised EPA that it will place similar, if not identical, requirements in 10 CFR Part 60 which does apply to Yucca Mountain.
} 
Studies completed by the Waste Isolation Systems Panel (WISP, 1983) and the YMP (unpublished) show that releases from unsăturated repositories in areas with low groundwater flow rates could meet the EPA containment requirements, but after 10,000 years, could violate the dose limits given in the individual and ground-water requirements. If the proposed repository at Yucca Mountain could not meet these 100,000-year dose limits, the site would have to be abandoned and $\$ 22.8$ billion (1988 dollars) would be needed to find a suitable replacement (Pflum et al., 1993a).

The EPA should also examine the costs and benefits of the life span of the waste package container. Durable (and expensive) containers may be needed to provide the level of confidence and protection that the standards demand, particularly for releases of gaseous carbon-14. Because gaseous carbon-14 poses a very small health threat to individuals, an analysis of EPA regulation that requires stringent containment of carbon-14 should be reviewed.

The incremental costs to contain gaseous carbon-14 for 10,000 years versus 1,000 years ranges from $\$ 2.1$ billion (Sanford Cohen and Associates, 1992) to $\$ 3.2$ billion (Pflum, 1993). Having access to these and other cost estimates, to over seventy-four references on carbon-14 (Park, 1991), and to a draft report prepared by the EPA Science Advisory Board (SAB, 1992); the EPA should realize that it is not cost-effective to attempt to reduce the minor (insignificant) health risk posed by gaseous releases of carbon-14. 


\section{Appendix A}

\section{SELECTED REGULATORY ACTIVITIES AND PRODUCTS}

This appendix provides the costs to produce three regulatory documents and the costs to hold meetings between the NRC and DOE. These few examples of regulatory costs that were incurred between 1983 and 1993 total $\$ 54.67$ million.

Site Characterization Plan $\ldots \ldots \ldots \ldots \ldots \ldots \ldots \ldots \ldots \ldots \ldots \$ \$ \$ 40.00$ million

The Site Characterization Plan (SCP) is a regulatory document that describes the proposed Yucca Mountain site and the future plans and studies to be carried out during site characterization (DOE, 1988). This includes detailed descriptions of the site as it was known in 1988 on such items as the geology, hydrology, climatic conditions, rock properties, etc. and proposed plans for site characterization; design of a potential repository, waste package, engineered barrier system; and needed performance assessment studies. The document is in eight chapters; the first five chapters containing detailed site information and the remaining three chapters containing descriptions of a conceptual repository and waste package and a description of the tests, design studies, and performance assessment studies to be performed during site characterization to address the regulations. Costs reported here are only for the preparation, review, and issuance of the SCP in 1988. Many other subsequent costs have not been tabulated in this report and include cost of developing comment/response documents, modifications in study plans as a result of comments on the $\mathrm{SCP}$, and many other associated costs.

Site Characterization Program Baseline $\ldots \ldots \ldots \ldots \ldots \ldots \ldots \ldots . \$ 3.12$ million

This two-volume document (DOE, 1993) continuously updates and refines the site investigations described in some 104 study plans. Quality assurance requirements in 10 CFR 60 require these updates, and oversight groups, such as the NRC staff, often recommend the refinements. The site investigations will provide the data to address 
performance and design requirements specified in 40 CFR Part 191 and 10 CFR Part 60 and ultimately will help the NRC decide whether a geologic repository should be licensed.

The document organizes characterization into approximately eighteen programs which are driven by one or more regulatory requirement. 'For example, the programs for various geotechnical and climatological investigations are driven by 10 CFR 60.122 and 40 CFR 191.13; programs for human intrusion are driven by 40 CFR 191.13 and 191.14; land ownership by 10 CFR 60.121; mineral rights by 10 CFR 60.21 and test controls are driven by 10 CFR 60 Subpart F.

We estimate that 48,000 person-hours ${ }^{10}$ have thus far been spent to produce and maintain this controlled document.

Exploratory Studies Facility Design Requirements. ..........\$3.64 million

This two volume document (DOE, 1992b) was prepared primarily to satisfy NRC requirements (10 CFR Part 60) and to close objections raised by the NRC staff (NRC, 1989). It constrains the excavations and in situ testing so that they will not adversely affect waste isolation or interfere with one another. At the same time the document must ensure that the excavations and testing are extensive enough to give the NRC staff all information they feel is necessary to comply with 10 CFR Part 60 and 40 CFR Part 191.

We estimate that 56,000 person-hours have thus far been spent to produce this document.

Meetings Between the NRC and DOE $\ldots \ldots \ldots \ldots \ldots \ldots \ldots \ldots \ldots \$$ \$7.91 million

The NRC and DOE hold two types of public meetings: technical exchanges and formal meetings. The technical exchanges promote an open dialogue during which no commitments are made. The formal meetings allow development of official positions and established commitments that are documented in a meeting summary. Although rarely

${ }^{10}$ One professional person-hour is valued at $\$ 65.00$. 
attended by the EPA, these meetings focus upon regulatory issues which can be traced to the EPA standards.

Meeting topics are reviewed every six months and meeting schedules are updated weekly. A meeting agenda must be completed and posted at least ten working days before the meeting. Although the public is invited, mostly staff and contractors representing the NRC, DOE, the utilities, the Nuclear Waste Technical Review Board, and representatives of state and local governments attend.

Between 1983 and 1992 the NRC and DOE have held 187 meetings ${ }^{11}$ (NRC, 1993) whose costs total $\$ 7.91$ million. On average, each meeting draws 23 people (12 from out of town and 11 locals), lasts one and half days, and costs $\$ 42,000.00$. The costs include salaries and travel (see Table 4.4.1-1), but do not include preparation expenses.

\footnotetext{
11 We do not include the NRC "visits" to Yucca Mountain and the NRC observations of the DOE quality assurance audits and surveillances. Between June, 1987 and December, 1992, these visits and observations total 101 (NRC, 1992).
} 


\section{COST OF MEETINGS BETWEEN THE NRC \& DOE}

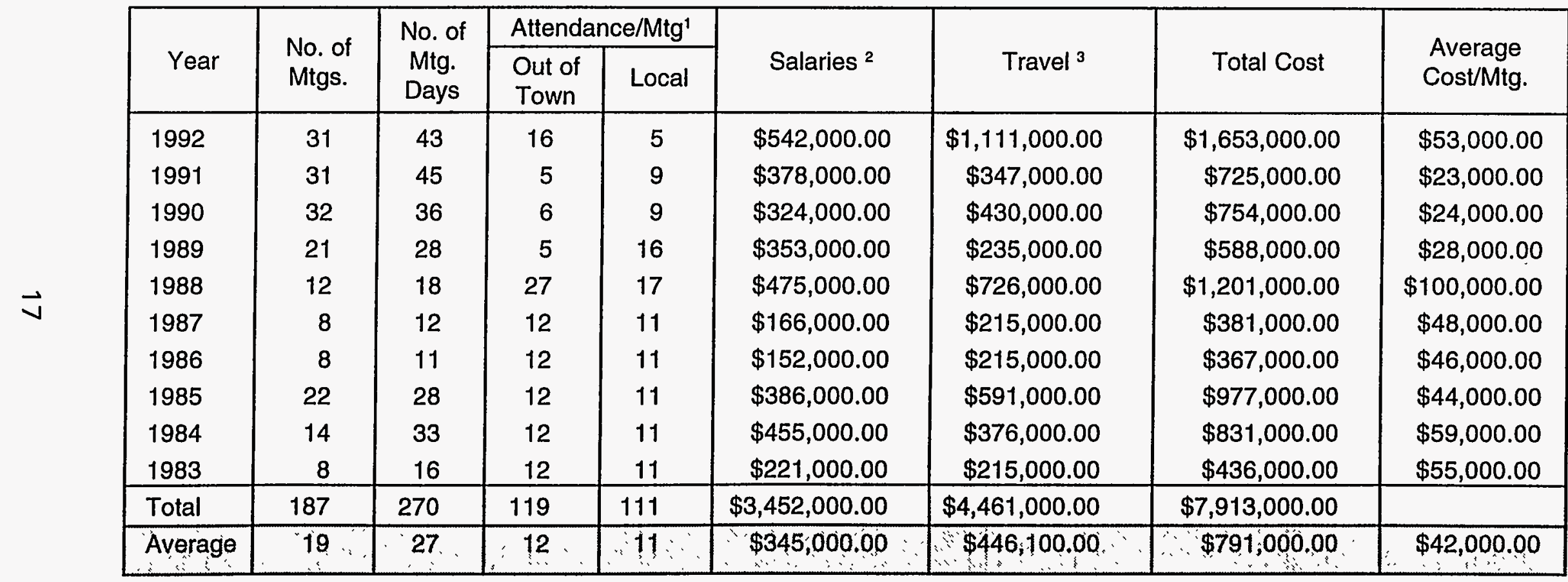

1 From 1988 to 1992 , meeting attendance is the yearly average based on meeting records. From 1983 to 1987 , records were not available so attendance was based on the average from 1988 to 1992.

2 Salaries are assumed at $\$ 600.00 /$ day/person.

3 Travel costs include airfare (500.00), 3 days government per diem (144.00/day), 3 days car rental ( $\$ 36.00 /$ day) and 2 days salary for travel time. 


\section{References}

DOE (U.S. Department of Energy), 1993, "Site Characterization Program Baseline Document" (YMP/CM-0011, Rev 10), Yucca Mountain Site Characterization Project Office, Las Vegas, Nevada, January 15, 1993.

DOE (U.S. Department of Energy), 1992a, "Technical Assistance to the U.S. Environmental Protection Agency on 40 CFR Part 191," Washington, D.C., August 10, 1992. .

DOE (U.S. Department of Energy), 1992b, "Exploratory Studies Facility Design Requirements" (YMP/CM-0019), Yucca Mountain Site Characterization Project Office, Las Vegas, Nevada, July 22, 1992.

DOE (U.S. Department of Energy), 1991, letter from Paul L. Ziemer, Assistant Secretary, Environment Safety and Health, DOE to William G. Rosenburg, Assistant Administrator for Air and Radiation, EPA., December 5, 1991.

DOE (U.S. Department of Energy), 1988, "Site Characterization Plan - Yucca Mountain Site, Nevada Research and Development Area, Nevada" (DOE/RW-0199), Office of Civilian Radioactive Waste Management, Washington, D.C., January, 1988.

EPA (U.S. Environmental Protection Agency), 1992, Draft, "Regulatory Impact Analysis For EPA's High-Level Waste Standard (40 CFR Part 191)," EPA, Office of Radiation Programs, Washington, D.C., August, 1992.

EPA (U.S. Environmental Protection Agency), 1985, "Final Regulatory Impact Analysis, 40 CFR Part 191, Environmental Standards for the Management and Disposal of Spent Nuclear Fuel, High-level and Transuranic Radioactive Wastes" (EPA 520/1-85-027), EPA Office of Radiation Programs, Washington, D.C., August, 1985.

Fifth Cir. (U.S. Fifth Circuit Court), 1991, "Corrosion Proof Fittings v. U.S. Environmental Protection Agency," 947 F. 2d 1201.

Little (Arthur D. Little and Associates), 1990, "High Level and Transuranic Wastes: Background Information Document," prepared for the U.S. Environmental Protection Agency, Washington, D.C., June 29, 1990.

NRC (U.S. Nuclear Regulatory Commission), 1993, "Selected NRC Products High-Level Waste Program, Division of HLW Management," Rockville, Maryland, January, 1993.

NRC (U.S. Nuclear Regulatory Commission), 1983 - 1993, "Budget Estimates and Actuals" (NUREG-0704; NUREG-1100, Vols. 1,2,3,4,5,6,7 and 8), Office of Standards Development, Rockville, Maryland. 
NRC (U.S. Nuclear Regulatory Commission), 1989, "NRC Staff Site Characterization Analysis of the Department of Energy's Site Characterization Plan, Yucca Mountain Site, Nevada " (NUREG-1347), Office of Nuclear Material Safety and Safeguards, Washington, D.C., August, 1989.

NRC (U.S. Nuclear Regulatory Commission), 1983, "Staff Analysis of Public Comments on Proposed Rule 10 CFR Part 60" (NUREG-0804), Washington, D.C., December, 1983.

NWPAA (Nuclear Waste Policy Act Amendments), 1987, "Amendments to the Nuclear Waste Policy Act of 1982" Public Law 100-203 - December 22, 1987, 100th Congress, Title V, Washington, D.C., pp 236-266.

Park, U-Sun, 1991, "Regulatory Overview and Recommendations on a Repository's Release of Carbon-14," Science Applications International Corporation, Las Vegas, Nevada, January, 1991.

Pflum, C.G., Krishna, P. and Van Konynenburg, R., 1993, "Critical Comments on the U.S. Environmental Protection Agency Standards 40 CFR 191," Prepared for the U.S. Department of Environment, Safety and Health, Washington, D.C., January 14, 1993.

Pflum, C.G., 1993, "Carbon-14 Releases from an Unsaturated Repository: A Senseless But Expensive Dilemma," Waste Management '93, Tucson, Arizona, March 1, 1993.

SAB (Science Advisory Board), 1984, Letter, Herman E. Collier, Jr., Chairman, High-level Radioactive Waste Disposal Subcommittee, Science Advisory Board to William D. Ruckelshaus, Administrator, U.S. Environmental Protection Agency, February 17, 1984.

SAB (Science Advisory Board), 1992, Science Advisory Board Review of the Release of Carbon-14 in Gaseous Form from High-Level Waste Disposal," final draft report prepared by the Subcommittee on Carbon-14, prepared for the U.S. Environmental Protection Agency, Washington, D.C., December 17, 1992.

Sanford Cohen and Associates (SCA), 1992, "Issues Associated with Gaseous Releases of Radionuclides for a Repository in the Unsaturated Zone," July 20, 1992.

WISP (Waste Isolation Systems Panel), 1983, "A Study of the Isolation System for Geologic Disposal of Radioactive Wastes," National Academy Press, Washington, D.C.

Yalow, R. S., 1991, Radiation and Society, Interdisciplinary Science Reviews, Vol. 16, No. 4, pp. 1-6. 